Landscape in Sight 
This page intentionally left blank 


\section{Landscape in Sight}

\section{Looking at America}

John Brinckerhoff Jackson

Edited by Helen Lefkowitz Horowitz 
Published with assistance from the Charles A. Coffin Fund.

Permissions for use of texts appear on page 370 .

Copyright $\odot 1997$ by Yale University. All rights reserved. This book may not be reproduced, in whole or in part, including illustrations, in any form (beyond that copying permitted by Sections 107 and 108 of the U.S. Copyright Law and except by reviewers for the public press), without written permission from the publishers.

Designed by Rebecca Gibb. Set in types by Adobe Garamond and Nobel by The Marathon Group, Inc., Durham, North Carolina. Printed in the United States of America by

\section{Library of Congress Cataloging-in-Publication Data}

Jackson, John Brinckerhoff, 1909-1996

Landscape in sight : looking at America / John Brinckerhoff Jackson ;

edited by Helen Lefkowitz Horowitz.

p. $\mathrm{cm}$.

Includes bibliographical references and index.

ISBN 0-300-07II6-7 (alk. paper)

I. Landscape assessment-United States. 2. Human geography-United States. 3. ArchitectureUnited States. 4. United States-Description and travel. I. Horowitz, Helen Lefkowitz. II. Title. GF91.U6J317 1997

$304.2-\mathrm{DC}_{21}$

$96-48728 \mathrm{CIP}$

A catalogue record for this book is available from the British Library. The paper in this book meets the guidelines for permanence and durability of the Committee on Production Guidelines for Book Longevity of the Council on Library Resources.

IO $\quad 9 \quad 8 \quad 8 \quad 7 \quad 6 \quad 5 \quad 4$ 